\title{
Social cognition and executive function in borderline personality disorder: evidence of altered cognitive processes
}

\author{
Jonathan Adrián Zegarra-Valdivia, 'Brenda Nadia Chino Vilca ${ }^{1,2}$
}

Universidad Nacional de San Agustín de Arequipa, Perú.

2 Universidad Católica San Pablo, Arequipa, Perú.

Correspondence:

Jonathan Adrián Zegarra-Valdivia

CIDETI en Neurociencia Cognitiva y

Calidad de Vida, Instituto de Investiga-

ciones Sociales, Universidad Nacional de San Agustín.

Avenida Venezuela S/N, Cercado,

Arequipa, Perú

Phone: +51932 130 - 357

Email: jzegarrav@unsa.edu.pe

Received: 23 June 2018

Accepted: 28 November 2018

\section{Citation:}

Zegarra-Valdivia, J. A., Chino Vilca, B. N. (2019). Social cognition and executive function in borderline personality disorder: evidence of altered cognitive processes. Salud Mental $42(1), 33-41$.

DOI: $10.17711 /$ SM.0185-3325.2019.005

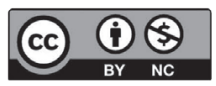

\begin{abstract}
Introduction. Social cognition (SC) and executive function (EF) research in borderline personality disorder (BPD) has proven to be controversial and lack of sufficient information about deficit patterns. Objective. Assess the contribution of SC and EF in the socio-emotional and cognitive patterns in BPD, as well as investigate the possible relationships between SC, EF, and clinic features in BPD. Method. The study evaluated 20 females with BPD in ambulatory hospitalization and 20 healthy women in social cognition ("Reading the mind through the eyes" and the IOWA gambling task) and executive function (with the Wisconsin Card Sorting Test, verbal fluency tasks; digit spam test and numbers-and-letters of the WAIS-III, Trail Making Test Form A and B). Results. The results show statistically-significant differences for the tasks evaluated in social cognition, the theory of mind $\left(u: 181, p<.001^{* *}\right)$, and the IOWA gambling task, score IOWA $4\left(p<.004^{*}\right)$, and IOWA 5 $\left.p<.003^{*}\right)$; and executive functioning, for example in the Wisconsin card sorting test, WCST1 were found $(p<$ $\left..003^{*}\right)$, WCST2 $\left(p<.004^{*}\right)$, WCST3 $\left(p<.018^{*}\right)$ or WCST4 $\left(p<.003^{*}\right)$. Digit span test and verbal fluency had significant differences compared to controls. Discussion and conclusion. The subdomains evaluated would be good endophenotypes as well as specific cognitive processes for research and rehabilitation.
\end{abstract}

Keywords: Neuropsychology, borderline personality disorder, social cognition, executive function.

\section{RESUMEN}

Introducción. La investigación sobre cognición social (SC) y funciones ejecutivas (EF) en el trastorno límite de la personalidad (TLP) ha arrojado datos controvertidos e insuficientes sobre los patrones de déficit. Objetivo. Evaluar la contribución de SC y EF en los patrones cognitivos en el TLP, así como investigar las posibles relaciones entre SC, EF y las características clínicas del TLP. Método. El estudio evaluó 20 mujeres con TLP en hospitalización ambulatoria y 20 mujeres sanas en cognición social ("Leer la mente a través de los ojos" y la tarea de apuestas IOWA) y función ejecutiva (con la Prueba de clasificación de tarjetas de Wisconsin, tareas de fluidez verbal; y números y letras del WAIS-III, formulario de prueba de Trail Making A y B). Resultados. Se evidencian diferencias estadísticamente significativas en cognición social, la teoría de la mente ( $p<$ $\left..001^{* *}\right)$ y la tarea de apuestas IOWA, puntúan IOWA $4\left(p<.004^{*}\right)$ e IOWA $5\left(p<.003^{*}\right)$ y en funciones ejecutivas; por ejemplo, en la prueba de clasificación de tarjetas de Wisconsin, se encontraron WCST1 $\left(p<.003^{*}\right)$, WCST2 $\left(p<.004^{*}\right)$, WCST3 $\left(p<.018^{*}\right)$ o WCST4 $\left(p<.003^{*}\right)$. Además, la prueba de amplitud de dígitos o la fluidez verbal tuvieron diferencias significativas en comparación con los controles. Discusión y conclusión. Los subdominios evaluados serían buenos endofenotipos, así como también procesos cognitivos específicos para investigación y rehabilitación.

Palabras clave: Neuropsicología, trastorno límite de la personalidad, cognición social, funciones ejecutivas. 


\section{INTRODUCTION}

Borderline personality disorder (BPD) is a severe mental disease with a pervasive pattern of emotional instability, suicidal-attempts, and marked impulsivity that begins in adolescence and early adulthood (American Psychiatric Association, 2013). DSM-5 criteria focus on the principal symptom, although in BPD are oscillatory and heterogeneous because they could result in over 100 different clinical variants, which affect the clinical presentation (Forti \& Forti, 2012). Nonetheless, clinic relevant characterization for epidemiologic studies shows a BPD prevalence between 1-6\% (Hughes, Crowell, \& Coan, 2012). It is the most common personality disorder (Hughes et al., 2012; Tajima \& de Anta, 2009; Tajima et al,. 2009) and epidemiological studies such as the one developed by Grant et al., (2008) point out that the prevalence of BPD does not differ according to gender. In the other hand, the American Psychiatric Association (2013) mentions that $75 \%$ of diagnosed cases are women. In agreement with it, the conclusion about gender prevalence is still controversial.

The clinic course of BPD patients is variable, and almost constantly unstable with acute periods of crisis, auto-mutilation, aggressive behavior, suicide attempts, drug abuse, etc. All of them comes along with an important affective correlate. In this case, the estimated prevalence increased $50 \%$ in patients attended in urgencies, and nearly $5 \%$ to $10 \%$ committed suicide (Paris, 2008). BPD patients usually show high co-morbidity rates for mood disorders, anxiety, and drug abuse (Leichsenring, Leibing, Kruse, New, \& Leweke, 2011).

A highlight is that $24 \%$ of the patients have hallucinatory and severe psychotic symptoms (Pope, Jonas, Hudson, Cohen, \& Tohen, 1985) and 75\% also show paranoid ideation and dissociative experiences. Several studies show that psychotic symptoms are temporal, and related to elevated trauma/stress periods (Igarashi et al., 2010; Zanarini, 2000). Recent studies suggest that those symptoms are present in early childhood (Yee, Korner, McSwiggan, Meares, \& Stevenson, 2005), being a source of important clinic traits.

The etiology of BDP is complex, and researchers and clinicians do not have an etiopathogenic model that integrates all its characteristics. However, a multidimensional approach (between neurobiology to cognitive and social aspects) is more appropriate in BPD and other neuropsychiatric disorders.

Indeed, some studies have related some neurocognitive profiles in many disorders to social cognition (Andreou et al., 2015), a sum of mental (cognitive and socio-emotional) processes implicated in social interaction, and adaptive behavior.

Perhaps, in BPD patients, data are contradictory as well as unclear upon how these processes are related to clinic features. For example, the mentalizing, a core process in social cognition, refers to cognitive and emotional ability to understand your own mind and that of the others. Data reveals that BPD patients have normal or even better mentalizing abilities (Arntz, Bernstein, Oorschot, \& Schobre,
2009; Arntz \& Haaf, 2012; Fertuck et al., 2009; Franzen et al., 2011; Lynch et al., 2006). Nonetheless, other studies suggest an impairment in mentalizing (Robin et al., 2012; Roepke, Vater, Preißler, Heekeren, \& Dziobek, 2012; Unoka, Fogd, Füzy, \& Csukly, 2011).

Although the mentalizing process was initially described in autism spectrum disorder and schizophrenia (Baron-Cohen, Leslie, \& Frith, 1985; Baron-Cohen, Wheelwright, Hill, Raste, \& Plumb, 2001; Fernández-Abascal, Cabello, Fernández-Berrocal, \& Baron-Cohen, 2013; Gavilán-Ibáñez \& García-Albea, 2013), is not limited to them. Indeed, in relation BPD, some specific patterns can differ [e.g., under-mentalizing vs. over-mentalizing (Andreou et al., 2015; Vaskinn et al., 2015)].

Another subdomain in social cognition is the decision-making process. Is a cognitive function involved with reflecting on the consequences of a certain choice (Bechara, 2005; Bechara, Damasio, Damasio, Anderson, 1994) based on somatic markers (Damasio, 1994). BPD patients seem to have more difficulties to learn from negative feedback (Svaldi, Philipsen, \& Matthies, 2012). Also, these processes have shown some relation with other cognitive abilities, but only a few have shown statistically significant relations (Toplak, Sorge, Benoit, West, \& Stanovich, 2010).

On the other hand, executive functions, which are a set of processes such as working memory, attention, shifting, planning, etc., that people use to control and coordinate their cognitive abilities and behavior to achieve specific objectives, have not been studied enough in BPD. Nevertheless, the dorsolateral prefrontal cortex executive function process has shown a normal range performance in BPD (LeGris, Links, van Reekum, Tannock, \& Toplak, 2012) or at least memory impairments in subgroups of BPD subjects (Fertuck, Lenzenweger, Clarkin, Hoermann, \& Stanley, 2006). So far, certain possible underpinnings of executive functions in BPD have received little attention.

In summary, social cognition studies suggest impairment in BPD but are still unclear or contradictory. As well as decision-making and executive function evidence have not been consistently studied in BPD. Therefore, the aims of this study are to assess the contribution of social cognition and executive function to socio-emotional and cognitive patterns in BPD, as well as to investigate the possible relationships between social cognition tasks and EF measures and clinic features in BPD.

\section{METHOD}

\section{Participants}

The clinic group consisted of 20 females with BPD in ambulatory hospitalization, medicated, and right-handed. All of them were diagnosed with DSM-5 criteria (American 
Psychiatric Association, 2013). Patients had not used drugs or alcohol for at least three months before the assessment and those who had a history of schizophrenia, psychotic disorder, bipolar and affective disorder were excluded. The mean time of disease was 11.95 years $(S D \pm 6.73)$. Patients had a mean age of 32.40 years ( $S D \pm 11.82$ years), and had high-school diplomas. The control group consisted of 20 healthy women with no history of mental diseases (mean age of $33.50 \pm 11.66$ ) with the same educational level.

Regarding the clinical characteristics of the sample, $100 \%$ of the patients attempted suicide on at least two occasions in their life, with a maximum of seven attempts. They consumed some psychotropic substances in their life $(95 \%)$, mostly alcohol $(60 \%), 15 \%$ of them used marijuana, $10 \%$ cocaine, and $10 \%$ had used multiple substances. They also had a history of sexual assault at some point in their life $(80 \%)$ (Table 1).

\section{Neuropsychological test}

For assessing our domains of interest we used a flexible neuropsychological battery. To assess social cognition, the "Reading the mind in the eyes" (Baron-Cohen et al., 2001) and the "IOWA Gambling task" (Brevers, Bechara, Cleeremans, \& Noël, 2013; Bechara, Damasio, Tranel, \& Damasio, 2005; Bechara, 2004) was performed.

The IOWA Gambling task was in virtual format (Psychology Experimental Building Language, [Mueller \& Piper, 2014]), and evaluated the decision-making emotional

Table 1

Characteristics of the sample

\begin{tabular}{|c|c|c|c|}
\hline & & $\begin{array}{l}\text { Control Group } \\
(n=20)\end{array}$ & $\begin{array}{c}\text { Clinic Group } \\
(n=20)\end{array}$ \\
\hline $\mathrm{Age}^{\mathrm{a}}$ & & $33.50 \pm 11.669$ & $32.40 \pm 11.829$ \\
\hline Sex & Females & $100 \%$ & $100 \%$ \\
\hline \multirow[t]{3}{*}{ Schooling } & High School & $30 \%$ & $40 \%$ \\
\hline & Technician & $25 \%$ & $20 \%$ \\
\hline & Professional & $45 \%$ & $40 \%$ \\
\hline \multirow[t]{2}{*}{ Suicidal attempts ${ }^{b}$} & Presence & ------- & $100 \%$ \\
\hline & Absence & ------- & ------- \\
\hline \multirow[t]{2}{*}{ Drug abuse $e^{b, c}$} & Presence & ------- & $95 \%$ \\
\hline & Absence & ------- & $5 \%$ \\
\hline \multirow[t]{5}{*}{ Kind of drug abuse } & None & $65 \%$ & $5 \%$ \\
\hline & Alcohol & $35 \%$ & $60 \%$ \\
\hline & Marijuana & ------- & $15 \%$ \\
\hline & Cocaine & ------- & $10 \%$ \\
\hline & Multiple drugs & ------- & $10 \%$ \\
\hline \multirow[t]{2}{*}{ Sexual mishandling ${ }^{\mathrm{b}}$} & Presence & ------- & $80 \%$ \\
\hline & Absence & ------- & $20 \%$ \\
\hline Disease time $^{a}$ & & ------ & $11.95 \pm 6.739$ \\
\hline
\end{tabular}

character, to determine the risk-benefit following the selection of four possible cards. At all times the assessed subject would know how to make their decisions or not profits, and after 100 attempts the amount of successes/failures that mediated somatic markers (Bechara, 2004) were measured. An emotional learning curve with five principal scores of each 20 responses was designed. The purpose of the game is to obtain the greatest possible reward.

Theory of mind or advance meta-representational skills were evaluated with the "Reading the mind in the eyes" (Baron-Cohen et al., 2001). We showed the subjects 36 images of human faces expressing a complex mental state whether thought, intention, or emotion, through facial gestures and particularly the eyes. Around the image there were adjectives that described the mental state and thus allowed four possible choices by the subject. This allowed the detection and discrimination of a social stimulus in the immediate environment (Sabbagh, 2004). Following the presentation of each image, we also requested the sexual identity of the people in the pictures as a control measure of perceptual skills.

Finally, to assess the executive function, we performed the letters and numbers sequence test, digit-spam test -direct and reversible, from the WAISS-III (Wechsler, 1977), the trail making test, form A and B, as the verbal fluency, semantic and phonologic (Jaichenco, Wilson, \& Ruiz, 2007). These tests evaluated executive functions, a "global" concept that includes processes such as concentration, attention, working memory, sequencing, planning, manipulation, and display of stimuli, change control and inhibition, lexical access, and semantic information retrieval (Villodre et al., 2006). Additionally, we used the Wisconsin Card Sorting Test -a particularly sensitive test for frontal dysfunction-, which is a measure of executive function that requires planning strategies, organized environmental investigations and use of "feedback" to change schemes (De la Cruz, 2001).

This was an ex post fact to retrospective study (Montero \& León, 2007) with two groups. We sought to measure the performance in neuropsychological tasks at a given point of time after the event of interest comparing both groups. A non-probabilistic sampling was used (Hernández, Fernández, \& Baptista, 2010).

\section{Testing procedure}

Subjects were tested individually in a quiet room at the hospital. The sequence in which tests were administered was identical for all subjects. The procedure took two sessions (almost two hours). Patients were tested in the morning at 10 a.m., and had 15 minutes to relax between sessions.

\section{Ethical statement}

The study was approved by the Ethics Board of a mental health hospital in Arequipa, in accordance with the decla- 
ration of Helsinki. All participants were informed about the aims of the study and gave written informed consent. All data were collected in an anonymous database.

\section{Data analysis}

Statistical analysis was performed with SPSS version 20 (SPSS, Inc., USA). Contrast tests of the parametric and nonparametric type were used, depending on the Kolmogorov-Smirnov normality test and the variance homogeneity test (Levene). The analyses of participants' learning curves in the IOWA gambling Task were carried out via a repeated measures ANOVA and Bonferroni post hoc analysis. We also used the Spearman correlation between variables. Results were significant with $* p<.05$, and $* * p<.01$.

\section{RESULTS}

The core cognitive processes in social cognition are theory of mind and decision-making mediated by somatic markers. In theory of mind evaluation, the "Reading the mind in the

Table 2

Sample characteristics and clinical variables of women with borderline personality disorder and healthy comparison subjects

\begin{tabular}{|c|c|c|c|c|c|}
\hline \multirow[b]{2}{*}{ Social cognition } & \multicolumn{2}{|c|}{$\begin{array}{l}\text { Control group } \\
\qquad \begin{array}{c}(n=20) \\
\mathrm{M} \pm \mathrm{SD}\end{array}\end{array}$} & \multirow[t]{2}{*}{$\begin{array}{l}\text { Clinic group } \\
\qquad \begin{array}{c}(n=20) \\
\mathrm{M} \pm \mathrm{SD}\end{array}\end{array}$} & \multirow[t]{2}{*}{$u$} & \multirow[t]{2}{*}{$p$} \\
\hline & & & & & \\
\hline ToM-Sex recognition & 34.15 & \pm 1.268 & $33.95 \pm 1.099$ & 181.000 & .620 \\
\hline ToM-Gaze recognition & 24.0 & \pm 3.325 & $20.70 \pm 3.164$ & 96.000 & $.004^{*}$ \\
\hline IOWA $1^{\mathrm{a}}$ & -.85 & \pm 1.387 & $-.20 \pm 3.548$ & .750 & $>.999$ \\
\hline IOWA $2^{\mathrm{a}}$ & 1.35 & \pm .813 & $1.95 \pm 4.136$ & .693 & $>.999$ \\
\hline IOWA $3^{a}$ & 2.80 & \pm .696 & $3.70 \pm 5.110$ & 1.040 & $>.999$ \\
\hline IOWA $4^{\mathrm{a}}$ & 4.60 & \pm .940 & $1.60 \pm 5.175$ & 3.465 & $.004^{* *}$ \\
\hline IOWA $5^{\mathrm{a}}$ & 5.15 & \pm .988 & $2.00 \pm 4.267$ & 3.638 & $.002^{* *}$ \\
\hline \multicolumn{6}{|l|}{ Executive function } \\
\hline WCST 1 & 80.50 & \pm 5.346 & $63.55 \pm 16.321$ & 93.500 & $.003^{*}$ \\
\hline WCST 2 & 19.25 & \pm 5.447 & $36.15 \pm 16.246$ & 96.500 & $.004^{*}$ \\
\hline WCST 3 & 10.65 & \pm 3.897 & $19.15 \pm 12.550$ & 113.500 & $.018^{*}$ \\
\hline WCST 4 & 8.15 & \pm 3.543 & $16.70 \pm 10.413$ & 93.500 & $.003^{*}$ \\
\hline WCST 5 & 10.55 & \pm 3.137 & $19.35 \pm 9.499$ & 92.000 & $.003^{*}$ \\
\hline WCST 6 & 71.80 & \pm 8.224 & $47.95 \pm 18.483$ & 64.000 & $.001^{* *}$ \\
\hline WCST 7 & 6.00 & \pm 0.00 & $4.05 \pm 1.669$ & 70.000 & $.001^{* *}$ \\
\hline WCST 8 & 11.15 & \pm 0.813 & $18.00 \pm 15.583$ & 125.000 & $.043^{*}$ \\
\hline WCST 9 & 0.15 & \pm 0.366 & $0.70 \pm 0.979$ & 135.500 & .081 \\
\hline WCST 10 & .400 & \pm 1.930 & $-5.75 \pm 10.254$ & 95.000 & $.004^{*}$ \\
\hline Total time & 16.15 & \pm 3.675 & $17.85 \pm 5.905$ & 171.500 & .445 \\
\hline Letters and numbers ${ }^{b}$ & 5.65 & \pm 0.671 & $5.60 \pm 1.847$ & 192.500 & .841 \\
\hline Direct digits ${ }^{a}$ & 5.95 & \pm 1.050 & $7.55 \pm 1.432$ & 75.000 & $.001^{* *}$ \\
\hline Reverse digits ${ }^{a}$ & 4.40 & \pm 0.995 & $4.30 \pm 1.689$ & 186.500 & .718 \\
\hline TMT A & 33.55 & \pm 6.168 & $51.50 \pm 22.758$ & 67.500 & $.001^{* *}$ \\
\hline Time $-1^{\circ}$ error & .00 & \pm .00 & $2.50 \pm 6.932$ & 170.000 & .429 \\
\hline TMT B & 74.65 & \pm 11.421 & $135.90 \pm 84.298$ & 109.000 & $.013^{*}$ \\
\hline Time $-1^{\circ}$ error & 1.90 & \pm 6.164 & $21.95 \pm 30.045$ & 80.000 & $.001^{* *}$ \\
\hline Phonological fluency & 16.30 & \pm 3.097 & $12.70 \pm 3.435$ & 93.000 & $.003^{*}$ \\
\hline Semantic fluency & 22.20 & \pm 2.949 & $18.50 \pm 4.310$ & 100.000 & $.006^{*}$ \\
\hline
\end{tabular}

Note: WCST 1: percentage of success; WCST 2: error percentage; WCST 3: perseverative response percentage; WCST 4: error perseverative percentage; WCST 5: error non-perseverative percentage; WCST 6: conceptual response; WCST 7: number of categories completed; WCST 8: attempts in the first category; WCST 9: failure of attentional set; WCST 10: learn to learn score;

${ }^{\text {a }}$ Post hoc Bonferroni analysis after Repeated measures ANOVA;

${ }^{b}$ two subjects in control group make a perseverative mistakes;

$u$ : Mann-Whitney U test:

${ }^{*} p<.05$;

${ }^{* *} p<.001$ 
eyes" test does not find any difference for recognition of sex in gaze $(u: 181, p<.620)$; in relation with gaze recognition of intentions, thoughts and emotion, statistically significant differences between BPD patients and the control group $(u$ : $96, p<.004^{*}$ ) were found (Table 2 ).

In Figure 1, the performance of these groups is presented. The theory of mind in BPD is clearly reduced compared with a healthy control group. The absence of differences in sex recognition displays a preserve perception process in BPD.

Regarding the next process of social cognition, the decision-making mediated by somatic markers, we used a mixed-design Repeated Measures ANOVA analysis to compared control versus clinical learning's curves (IOWA scores - and groups factor) on IOWA gambling task performance across blocks. The main effect of IOWA across time scores was found $\left(F=15.51 ; p=.0001^{* *}\right)$. But, the effect of groups (total scores in all trials) was not found $(F=1.277$; $p=.2726$ ). Nonetheless, a main interaction effect (Block per Group) was observed $(F=5.775 ; p=.0004 * *)$ between blocks $4(p=.0044)$ and $5(p=.0025)$. These results suggest that learning curves were significantly different between the BPD and the control group. Showing the last group as a better performance after 60 trials.

Figure 2 displays an emotional-learning curve in this task. The healthy control group took more advantageous choices over time agreeable with feedback across elections. In contrast, the BPD group took disadvantageous choices and their feedback did not show an effect in better selection. Over time patients grew more impulsive, took risky elections, and, this is related with severe BPD symptomatology. For the executive function (Table 3), the Wisconsin card sorting test display significant differences in its distinct scores, percentage of success WCST1, $(u: 93.5, p<.003 * *)$, error percentage WCST $2(u: 96.5, p<.004 * *)$ and perseverative response percentage WCST $3\left(u: 113.500, p<.018^{*}\right)$. BPD

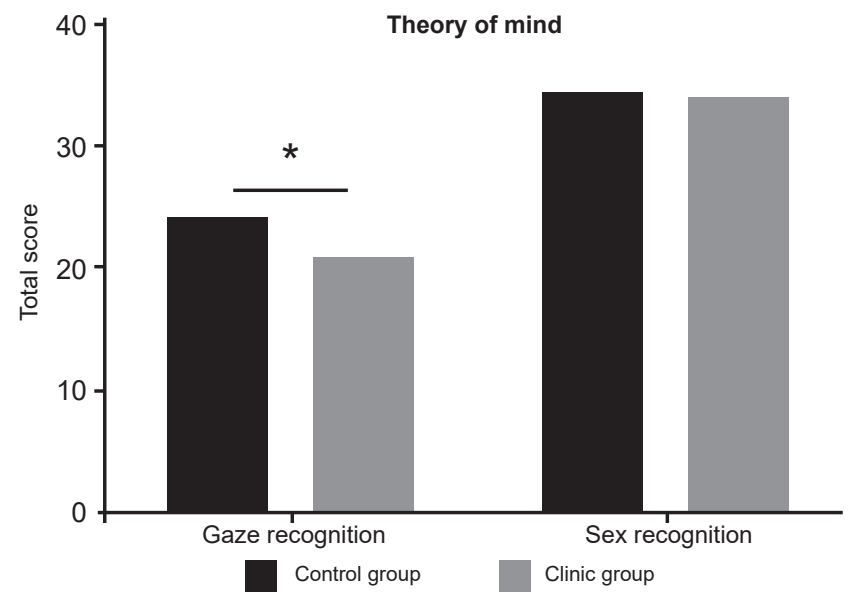

Figure 1. Reading the mind in the eyes. Comparison between clinic and control group. BPD patients display worse recognition of gaze than controls. patients presented also differences in error perseverative percentage ( $u$ : 93.5, $\left.p<.003^{* *}\right)$, error non-perseverative percentage WCST5 ( $\left.u: 92, p<.003^{* *}\right)$, as well as conceptual response WCST6 $\left(u: 64, p<.001^{* *}\right)$.

In relation to the number of categories completed, WCST 7 significant differences $(u: 70, p<.000 * *)$ were also obtained, as well as attempts in the first category WCST8 $(u: 125, p<.043 *)$. Failure of attentional set WCST 9 score showed no difference $(u: 135, p<.081)$. The WCST 10 score, learn to learn, showed significant differences (or: 95 , $p<.004 * *)$ between subjects. Run time showed no difference between both groups (or: 171.5, $p<.445$ ). Number and letter sequence from WAIS-III displayed no significant difference $(u$ : 192, $p<.841)$, as digit-span reverse test $(u$ : 103.5, $p<.109$ ). Digit-span direct test showed ( $u$ : $117, p<$ .255) a significant difference for both groups.

Likewise, trail making test form A displayed significant differences between groups ( $u: 15, p<.001 * *)$, but not in the occurrence for the first error $(u: 170, p<.429)$. Trail making test form B showed difference in time $\left(u: 80, p<.001^{* *}\right)$ and execution ( $\left.u: 109, p<.013^{*}\right)$, respectively. Verbal fluency also showed statistically difference in semantic $(u: 100$, $\left.p<.006^{*}\right)$ and phonologic $\left(u: 93, p<.003^{*}\right)$ task.

Table 3 displayed a Spearman Rho correlation for two clinical variables (suicidal attempts and time disease), and neuropsychological test scores. Suicidal attempts correlated positively with time disease $\left(p \leq .001^{* *}\right)$ and negatively with gaze recognition of the "Reading the mind in the eyes" test $(p \leq .001 * *)$, as well as emotional-learning scores 4 th. $\left(p \leq .019^{*}\right)$ and 5th. $\left(p \leq .016^{*}\right)$, respectively. Correlates negatively with success percentage WCST $1\left(p \leq .004^{*}\right)$ and positively with error percentage $\operatorname{WCST} 2\left(p \leq .004^{*}\right)$, perseverative percentage response $\operatorname{WCST} 3\left(p \leq .005^{*}\right)$. Indicating a negatively correlation besides with semantic $\left(p \leq .012^{*}\right)$ and phonologic $\left(p \leq .005^{*}\right)$ verbal fluency.

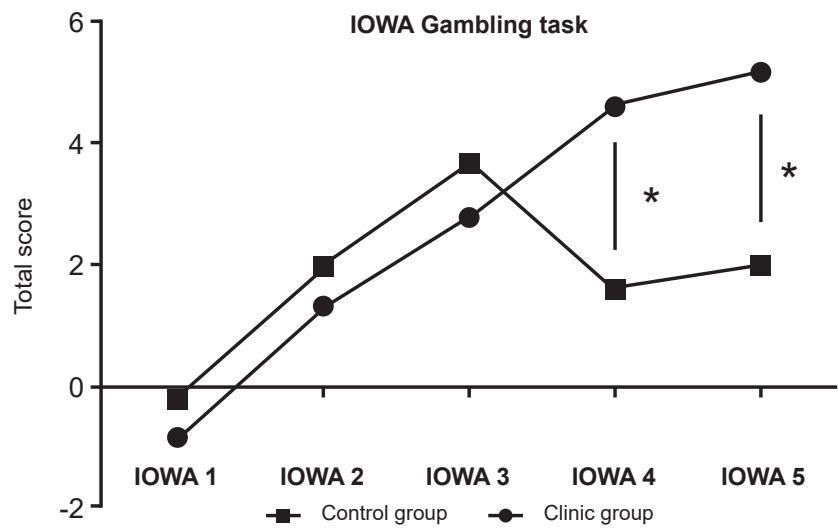

Figure 2. IOWA Gambling task. BPD patient shows |significant differences in IOWA scores 4 and 5 compared with controls. They take more disadvantage decisions showing more impulsivity than controls. 
Table 3

Spearman correlation

\begin{tabular}{|c|c|c|c|c|c|c|c|c|c|c|c|c|c|c|c|}
\hline & S. A. & D. T. & ToM S & ToM G & IOWA 3 & IOWA 4 & IOWA 5 & WCST 1 & WCST 2 & 2 WCST 3 & $3 \mathrm{WECH} 2$ & TMT A & TMT B & PVF & SVF \\
\hline \multirow[t]{2}{*}{ S.A. ${ }^{a, b}$} & 1 & $.891^{* *}$ & .000 & $-.502^{\star *}$ & .128 & $-.369^{*}$ & $-.378^{*}$ & $-.446^{* *}$ & $.435^{\star *}$ & $.383^{*}$ & $.457^{\text {** }}$ & $.583^{\star \star}$ & $.391^{*}$ & $-.398^{*}$ & $-.390^{*}$ \\
\hline & . & .000 & .998 & .001 & .431 & .019 & .016 & .004 & .005 & .015 & .003 & .000 & .013 & .011 & .013 \\
\hline \multirow[t]{2}{*}{ D. T. } & $.891^{\star *}$ & 1 & -.130 & $-.432^{* *}$ & .172 & -.287 & -.287 & $-.486^{* *}$ & $.483^{* *}$ & $.374^{*}$ & $.429^{* *}$ & $.602^{* *}$ & $.486^{\star *}$ & $-.434^{* *}$ & $-.395^{*}$ \\
\hline & .000 & . & .422 & .005 & .290 & .073 & .073 & .001 & .002 & .017 & .006 & .000 & .001 & .005 & .012 \\
\hline \multirow[t]{2}{*}{ ToM S } & .000 & -.130 & 1 & .215 & -.259 & -.248 & -.045 & .193 & -.179 & -.256 & -.062 & -.222 & -.124 & -.066 & .125 \\
\hline & .998 & .422 & $\cdot$ & .182 & .107 & .123 & .781 & .234 & .269 & .111 & .702 & .170 & .445 & .687 & .443 \\
\hline \multirow[t]{2}{*}{ ToM G } & $-.502^{* *}$ & $-.432^{* *}$ & .215 & 1 & -.093 & .129 & $.434^{* *}$ & .160 & -.186 & -.159 & .051 & $-.558^{* *}$ & -.293 & $.447^{* *}$ & $.339^{*}$ \\
\hline & .001 & .005 & .182 & . & .567 & .426 & .005 & .324 & .250 & .326 & .754 & .000 & .067 & .004 & .032 \\
\hline \multirow[t]{2}{*}{ IOWA 3} & .128 & .172 & -.259 & -.093 & 1 & .294 & .214 & $-.354^{*}$ & $.365^{\star}$ & .256 & .240 & .107 & .077 & .200 & .161 \\
\hline & .431 & .290 & .107 & .567 & . & .066 & .186 & .025 & .021 & .111 & .135 & .510 & .636 & .216 & .321 \\
\hline \multirow[t]{2}{*}{ IOWA 4} & $-.369^{*}$ & -.287 & -.248 & .129 & .294 & 1 & $.508^{* *}$ & .066 & -.045 & -.059 & -.265 & -.04 & .162 & .277 & $.337^{*}$ \\
\hline & .019 & .073 & .123 & .426 & .066 & . & .001 & .688 & .782 & .718 & .098 & .805 & .318 & .084 & .033 \\
\hline \multirow[t]{2}{*}{ IOWA 5} & -.378 & -.287 & -.045 & $.434^{\star *}$ & .214 & $.508^{\star *}$ & 1 & .022 & .002 & -.058 & -.048 & $-.321^{*}$ & .060 & $.455^{\star *}$ & .184 \\
\hline & .016 & .073 & .781 & .005 & .186 & .001 & $\cdot$ & .895 & .991 & .723 & .768 & .043 & .711 & .003 & .255 \\
\hline \multirow[t]{2}{*}{ WCST 1} & $-.446^{* *}$ & $-.486^{\star *}$ & .193 & .160 & $-.354^{*}$ & .066 & .022 & 1 & $-.996^{* *}$ & $-.889^{* *}$ & -.188 & $-.469^{* *}$ & -.294 & .279 & $.339^{*}$ \\
\hline & .004 & .001 & .234 & .324 & .025 & .688 & .895 & . & .000 & .000 & .244 & .002 & .065 & .081 & .033 \\
\hline \multirow[t]{2}{*}{ WCST 2} & $.435^{\star *}$ & $.483^{* *}$ & -.179 & -.186 & $.365^{*}$ & -.045 & .002 & $-.996^{* *}$ & 1 & $.883^{* *}$ & .171 & $.478^{* *}$ & .306 & -.276 & $-.323^{*}$ \\
\hline & .005 & .002 & .269 & .250 & .021 & .782 & .991 & .000 & . & .000 & .293 & .002 & .055 & .085 & .042 \\
\hline \multirow[t]{2}{*}{ WCST 3} & $.383^{*}$ & $.374^{*}$ & -.256 & -.159 & .256 & -.059 & -.058 & $-.889^{* *}$ & $.883^{* *}$ & 1 & .062 & $.427^{* *}$ & .135 & -.185 & -.280 \\
\hline & .015 & .017 & .111 & .326 & .111 & .718 & .723 & .000 & .000 & . & .703 & .006 & .407 & .254 & .080 \\
\hline \multirow[t]{2}{*}{ DDS } & $.457^{* *}$ & $.429^{* *}$ & -.062 & .051 & .24 & -.265 & -.048 & -.188 & .171 & .062 & 1 & .111 & .240 & .023 & -.209 \\
\hline & .003 & .006 & .702 & .754 & .135 & .098 & .768 & .244 & .293 & .703 & . & .497 & .136 & .888 & .196 \\
\hline \multirow[t]{2}{*}{ TMT A } & $.583^{\star *}$ & $.602^{* *}$ & -.222 & $-.558^{* *}$ & .107 & -.040 & $-.321^{*}$ & $-.469^{* *}$ & $.478^{\star *}$ & $.427^{* *}$ & .111 & 1 & $.550^{\star *}$ & $-.608^{* *}$ & $-.318^{*}$ \\
\hline & .000 & .000 & .170 & .000 & .510 & .805 & .043 & .002 & .002 & .006 & .497 & . & .000 & .000 & .046 \\
\hline \multirow[t]{2}{*}{ TMT B } & $.391^{*}$ & $.486^{* *}$ & -.124 & -.293 & .077 & .162 & .060 & -.294 & .306 & .135 & .240 & $.550^{* *}$ & 1 & $-.443^{* *}$ & -.294 \\
\hline & .013 & .001 & .445 & .067 & .636 & .318 & .711 & .065 & .055 & .407 & .136 & .000 & $\cdot$ & .004 & .066 \\
\hline \multirow[t]{2}{*}{ PVF } & $-.398^{*}$ & $-.434^{* *}$ & -.066 & $.447^{* \star}$ & .200 & .277 & $.455^{* *}$ & .279 & -.276 & -.185 & .023 & $-.608^{* *}$ & $-.443^{* *}$ & 1 & $.678^{* *}$ \\
\hline & .011 & .005 & .687 & .004 & .216 & .084 & .003 & .081 & .085 & .254 & .888 & .000 & .004 & . & .000 \\
\hline \multirow[t]{2}{*}{ SVF } & $-.390^{*}$ & $-.395^{\star}$ & .125 & $.339^{*}$ & .161 & $.337^{*}$ & .184 & $.339^{*}$ & $-.323^{*}$ & -.280 & -.209 & $-.318^{\star}$ & -.294 & $.678^{* *}$ & 1 \\
\hline & .013 & .012 & .443 & .032 & .321 & .033 & .255 & .033 & .042 & .080 & .196 & .046 & .066 & .000 & \\
\hline
\end{tabular}

Note: S.A.: Suicidal attempts; D.T.: Disease time; D.D.S.: Direct digit spam test; P.V.F.: Phonological verbal fluency; S.V.F.: Semantic verbal fluency;

a Coefficient correlation;

b Significance level;

${ }^{*} p<.05$

${ }^{* *} p \leq .0$.

Gaze recognition of theory of mind correlated positively with IOWA 5 score $\left(p \leq .005^{*}\right)$, as well as phonologic $(p \leq .004 *)$ and semantic $(p \leq .032 *)$ fluency. Besides gaze recognition correlated negatively with trail making test A $\left(p \leq .001^{* *}\right)$. IOWA 5 score correlated negatively with trail making test A ( $\left.p \leq .043^{*}\right)$, and positively with phonologic fluency $\left(p \leq .003^{*}\right)$. All variables of executive function exhibit a high correlation between them.

\section{DISCUSSION AND CONCLUSION}

The aim of this study was to evaluate the neuropsychological profile of BPD patients and compare it with a healthy control group. Appraising the social cognition and executive function cognitive process, and analyzing how they are related. The main result is that women with BPD are characterized by worse social cognition abilities and executive function when compared to the control group.

Regarding social cognition, theory of mind and decision-making were assessed. For the first one, BPD showed a normal recognition of sex as a control perceptual task. In contrast, recognition of intentions, thoughts, and emotions in BPD patients are less proficient. Perceptual emotional recognition in these patients are related to higher vigilance of social stimuli and worse stability in their relationships. Dysfunctional social processing is conditioned to mentalizing, while BPD patients are not only more vigilant for negative emotions, intentions, and thoughts but also reduce skills to integrate social stimulation with suitable interpretations of social context. Our results support the idea of deteriorating mentalizing processes in BPD (Domes, 
Schulze, \& Herpertz, 2009; Roepke et al., 2012; Unoka et al., 2011).

Nonetheless, these findings contradict the Krohn paradox, which assumes that BPD patients have normal or even better mentalizing abilities (Arntz \& Haaf, 2012; Fertuck et al., 2009). This paradox could be interpreted from different points of view. For example, differences in those studies might be associated with assessing different specific sub process in theory of mind, such as the cognitive theory of mind versus recognition of basic emotions. Methodological (e.g., test deployed, different stimulus, the social context of tasks) or even cultural, ethnic, and educational differences. It is also possible that clinic impairment characterizes for increased effects of child abuse or trauma, psychological severity, disease time or co-morbidity.

In our study, BPD patients were medically stable and controlled in ambulatory hospitalization. Of them, $80 \%$ mentioned a history of trauma such as sexual abuse, domestic violence, or neglect. Also 95\% had a history of drug abuse. This psychopathological severity is related to a less socio-cognitive process.

BPD patients have high clinical heterogeneity inter-individual, and intra-individual regard psychopathology display. Therefore, these patients may have a fluctuation in their cognitive process conditioning its psychopathology. Nonetheless, the impairment of the theory of mind could be considered as an endophenotype of this disorder. This process represents a complex control of socio-emotional and monitoring, and this handicap would be less stable and worse than in other disorders such as schizophrenia or autism spectrum disorder. It also explains dissociative states and paranoid symptoms, because BPD patients do not interpret correctly some mental or emotional states, or even they could not recognize and interpret their own mental states.

Traumatic events disturb socio-emotional and cognitive monitoring contributing to depersonalization or derealization symptoms, but also to emotional instability and disrupted social relationships. BPD patients do not recognize the mental states correctly and give those the wrong "cognitive and emotional tag" to the others and themselves (Fonagy \& Bateman, 2008). This shifting depends on context, promoting idealization-devaluating relations. It could make more vulnerable to emotional changes a wicked experience; this hypothesis need more support.

On the other hand, BPD patients display disadvantageous decision-making when compared to the control group. Patients persevere more and take more impulsive elections, presenting a "future myopia" (Damasio, 1994) for long-term rewards, looking not only for extensive stimulation and short-term rewards, but also for their ability to recognize and "tag" emotionally negative in the situations would be reduced, refusing "greater" adaptive advantage elections (Maurex et al., 2009; Svaldi et al., 2012). Inability to value negative feedback from context would support these results (Svaldi et al., 2012) and also the absence of cognitive strategies in their decision-making.

Other studies suggest the emotional-learning impairment in BPD and make evident signs of pre-frontal pathology. Poor decision-making is related to executive dysfunction such as working memory, attention, and planning may support mayor incidence of worse decisions, risk behavior, impulsivity, and symptoms severity (Svaldi et al., 2012). Our data suggest this lower processing in behavioral regulation, mental flexibility, and reverse learning as being related to high impulsivity. The BPD group displayed less cognitive monitoring, planning, working memory, attention, concentration, and behavioral regulation, which coincides with the findings other studies (Hagenhoff et al., 2013; Gvirts et al., 2012; Arza et al., 2009; Grosjean \& Tsai, 2007; Silvio, 2005; Stevens, Burkhardt, Hautzinger, Schwarz, \& Unckel, 2004).

Environmental stress or trauma experiences (Zanarini, 2000) affect behavioral regulation and patients are more susceptible to re-experiment trauma, increasing emotional instability, and worse integration of social context as a symptomatic buckle, promoting epigenetic changes (Klengel, Pape, Binder, \& Mehta, 2014; McGowan \& Szyf, 2010). "Top-down" cognitive and socio-emotional control regulates complex behavior in normal life; without it, cortical-subcortical processes are inflexible, simple, and stimulus-dependent (Miller, 2010).

Our domains of interest might involve in a neural system related with consciousness as cognitive and socio-emotional monitoring explaining cardinal symptoms in BPD. Those affecting processes have a neurobiological correlate in different cortical and subcortical systems (Jacob et al., 2013; Mier et al., 2013). Especially amygdala (Cullen et al., 2011), anterior cingulate, prefrontal-striatum-limbic (Wolf et al., 2011; Tebartz et al., 2003), prefrontal-temporal-parietal (O'Neill et al., 2014), and prefrontal-thalamic-cerebellar systems (Mier et al., 2013). Involving serotoninergic, glutamatergic, and dopaminergic neurotransmitter systems (Maurex, Zaboli, Ohmanm, Asberg, \& Leopardi, 2010; Homberg, 2012; Grosjean \& Tsai, 2007).

As discussed earlier, BPD is a serious disorder with a wide clinic heterogeneity and therapeutic difficulty. Neuropsychological profiles delimit functional and structural process implicate as well as help to elucidate specific endophenotype with genetic vulnerability of affected domains (Gottesman \& Gould, 2003; McCloskeya et al., 2009).

Reliable endophenotype for BPD are working memory, planning, and mental flexibility as executive processes (Arza et al., 2009). On the other hand, emotional dysregulation, theory of mind, and decision-making as social cognition process (Frick et al., 2012; Hughes et al., 2012; Roepke et al., 2012; Preißler, Dziobek, Ritter, Heekeren, \& Roepke, 2010; Domes et al., 2009). Specific subdomains of social cognition and executive function would be good endophe- 
notypes as well as specific cognitive processes for research, and should be objective of specific rehabilitation for BPD patients (Arza et al., 2009). In conclusion, patients stabilized with borderline personality disorder display differences in social cognition and executive function compared with healthy controls. Cognitive and socio-emotional domains are of special interest in clinical practice to address them as endophenotype or predictors of disease course and directing therapeutic intervention.

\section{Limitations}

One limitation observed in this study concerns the small sample size of the study and the potential sample bias of the screening phase. Additionally, the use of more ecological tests, for example, in more complex scenes of social interactions, as well as studies that consider sex differences, may advance understanding of borderline phenotypes.

\section{Funding}

None.

\section{Conflict of interests}

The authors declare that they have no conflict of interests.

\section{Acknowledgements}

The authors would like to thank the participants in this study.

\section{REFERENCES}

American Psychiatric Association. (2013). Diagnostic and Stadistical Manual of Mental Disorders. Washington: American Psychiatric Association.

Andreou, C., Kelm, L., Bierbrodt, J., Braun, V., Lipp, M., Yassari, A. H., \& Moritz, S. (2015). Factors contributing to social cognition impairment in borderline personality disorder and schizophrenia. Psychiatry Research, 229(3), 872-879. doi: 10.1016/j.psychres.2015.07.057

Arntz, A., Bernstein, D., Oorschot, M., \& Schobre, P. (2009). Theory of mind in borderline and cluster-C personality disorder. The Journal of Nervous and Mental Disease, 197(11), 801-807. doi: 10.1097/NMD.0b013e3181be78fb

Arntz, A. \& Haaf, J. T. (2012). Social cognition in borderline personality disorder: Evidence for dichotomous thinking but no evidence for less complex attributions. Behaviour Research and Therapy, 50(11), 707-718. doi: 10.1016/j. brat.2012.07.002

Arza, R., Díaz, M., López, C., Fernández, N., López, J. J., \& Carrasco, J. L. (2009). Rehabilitación neuropsicológica en pacientes con trastorno límite de personalidad: una serie de casos. Actas Españolas de Psiquiatría, 37(4), 236239.

Baron-Cohen, S., Leslie, M., \& Frith, U. (1985). Does the autistic child have a "theory of mind"?. Cognition, 21(1), 37-46. doi: 10.1016/0010-0277(85)90022-8

Baron-Cohen, S., Wheelwright, S., Hill, J., Raste, Y., \& Plumb, I. (2001). The "Reading the Mind in the Eyes" Test revised version: A study with normal adults, and adults with Asperger syndrome or high-functioning autism. Journal of Child Psychology and Psychiatry, and Allied Disciplines, 42(2), 241-251. doi: 10.1111/1469-7610.00715

Bechara, A. (2005). Decision making, impulse control and loss of willpower to resist drugs: A neurocognitive perspective. Nature Neuroscience, 8(11), 1458-1463. doi: $10.1038 / \mathrm{nn} 1584$
Bechara, A., Damasio, H., Tranel, D., \& Damasio, A. (2005). The Iowa Gambling Task and the somatic marker hypothesis: Some questions and answers. Trends in Cognitive Science, 9(4), 159-62. doi: 10.1016/j.tics.2005.02.002

Bechara, A. (2004). The role of emotion in decision-making: Evidence from neurological patients with orbitofrontal damage. Brain and Cognition, 55(1), 30-40. doi: 10.1016/j.bandc.2003.04.001

Bechara, A., Damasio, A., Damasio, H., \& Anderson, S. (1994). Insensitivity to future consequences following damage to human prefrontal cortex. Cognition, 50(13), 7-12.

Brevers, D., Bechara, A., Cleeremans, A., \& Noël, X. (2013). Iowa Gambling Task (IGT): twenty years after-gambling disorder and IGT. Frontiers in Psychology, 4, 665. doi: 10.3389/fpsyg.2013.00665

Cullen, K., Vizueta, N., Thomas, K., Han, G., Lim, K., Camchong, J., .. \& Schulz, C. (2011). Amygdala Functional Connectivity in Young Women with Borderline Personality Disorder. Brain Connectivity, 1(1), 61-71. doi: 10.1089/ brain.2010.0001

Damasio, A. (1994). El error de Descartes: La razón de las emociones. Chile: Andrés Bello.

De la Cruz, M. (2001). Test de Clasificación de Tarjetas de Wisconsin. Madrid: TEA.

Domes, G., Schulze, L., \& Herpertz, S. C. (2009). Emotion recognition in borderline personality disorder-a review of the literature. Journal of Personality Disorders, 23(1), 6-19. doi: 10.1521/pedi.2009.23.1.6

Fernández-Abascal, E. G., Cabello, R., Fernández-Berrocal, P., \& Baron-Cohen, S. (2013). Test-retest reliability of the "Reading the Mind in the Eyes" test: A oneyear follow-up study. Molecular Autism, 4(1), 33. doi: 10.1186/2040-2392-4-33

Fertuck, E., Jekal, A., Song, I., Wyman, B., Morris, M. C., Wilson, S. T., \& Stanley, B. (2009). Enhanced'Reading the Mind in the Eyes' in borderline personality disorder compared to healthy controls. Psychological Medicine, 39(12), 1979. doi: 10.1017/S003329170900600X

Fertuck, E. A., Lenzenweger, M. F., Clarkin, J. F., Hoermann, S., \& Stanley, B. (2006). Executive neurocognition, memory systems, and borderline personality disorder. Clinical Psychology Review, 26(3), 346-375. doi: 10.1016/j. cpr.2005.05.008

Fonagy, P. \& Bateman, A. (2008). The development of borderline personality disorder a mentalizing model. Journal of Personality Disorders, 22(1), 4-21. doi: 10.1521 /pedi.2008.22.1.4

Forti, L. \& Forti, A. (2012). Trastorno límite de la personalidad y conductas autolíticas. Revista Española de Medicina Legal, 38(4). doi: 10.1016/j.reml.2012.08.001

Franzen, N., Hagenhoff, M., Baer, N., Schmidt, A., Mier, D., Sammer, G., ... \& Lis, S. (2011). Superior Theory of Mind in borderline personality disorder: an analysis of interaction behavior in a virtual trust game. Psychiatry Research, 187(1-2), 224-233. doi: 10.1016/j.psychres.2010.11.012

Frick, C., Lang, S., Kotchoubey, B., Sieswerda, S., Dinu-Biringer, R., Berger, M., \& Barnow, S. (2012). Hypersensitivity in borderline personality disorder during mindreading. PLoS ONE, 7(8), 4-11. doi: 10.1371/journal.pone.0041650

Gavilán-Ibáñez, J. M. \& García-Albea, J. E. (2013). Theory of mind and language comprehension in schizophrenia. Psicothema, 25(4), 440-445. doi: 10.7334/ psicothema2012.357

Gottesman, I. \& Gould, T. (2003). The Endophenotype concept in psychiatry: Etymology and Strategic Intentions. American Journal of Psychiatry, 160(4), 636-645. doi: 10.1176/appi.ajp.160.4.636

Grant, B. F., Chou, S. P., Goldstein, R. B., Huang, B., Stinson, F. S., Saha, T. D., Smith, S. M., Dawson, D. A., Pulay, A. J., Pickering, R. P., ... Ruan, W. J. (2008). Prevalence, correlates, disability, and comorbidity of DSM-IV borderline personality disorder: results from the Wave 2 National Epidemiologic Survey on Alcohol and Related Conditions. The Journal of clinical psychiatry, 69(4), 533-45.

Grosjean, B. \& Tsai, G. (2007). NMDA neurotransmission as a critical mediator of borderline personality disorder. Journal of Psychiatry \& Neuroscience, 32(2), 103-115.

Gvirts, H., Harari, H., Braw, Y., Shefet, D., Shamay-Tsoory, S., \& Levkovitz, Y. (2012). Executive functioning among patients with borderline personality disorder and their relatives. Journal of Affective Disorders, 143(1-3), 261-264. doi: 10.1016/j.jad.2012.05.007

Hagenhoff, M., Franzen, N., Koppe, G., Baer, N., Scheibel, N., Sammer, G., ... \& Lis, S. (2013). Executive functions in borderline personality disorder. Psychiatry 
Research, 210(1), 224-231. doi: 10.1016/j.psychres.2013.05.016 Agregué doi

Hernández, R., Fernández, C., \& Baptista, P. (2010). Metodología de la Investigación. México: Mc Graw Hill.

Homberg, J. (2012). Serotonin and decision making processes. Neuroscience and Biobehavioral Reviews, 36(1), 218-236. doi: 10.1016/j.neubiorev.2011.06.001

Hughes, A. E., Crowell, S. E., \& Coan, J. A. (2012). A developmental neuroscience of borderline pathology: emotion dysregulation and social baseline theory. Journal of abnormal child psychology, 40(1), 21-33. doi: 10.1007/s10802-011-9555-x

Igarashi, H., Hasui, C., Uji, M., Shono, M., Nagata, T., \& Kitamura, T. (2010). Effects of child abuse history on borderline personality traits, negative life events, and depression: A study among a university student population in Japan. Psychiatry Research, 180(2-3), 120-125. doi: 10.1016/j.psychres.2010.04.029

Jaichenco, V., Wilson, M., \& Ruiz, A. (2007). "Evaluación del lenguaje”. In D. Burin, M. Drake, \& P. Harris, (eds.), Evaluación neuropsicológica en adultos. Paidós: Argentina.

Jacob, A. G., Zvonik, K., Kamphausen, S., Sebastian, A., Maier, S., Philipsen, A., \& Tüscher, O. (2013). Emotional modulation of motor response inhibition in women with borderline personality disorder: An fMRI study. Journal of Psychiatry and Neuroscience, 38(3), 164-172. doi: 10.1503/jpn.120029

Klengel, T., Pape, J., Binder, E. B., \& Mehta, D. (2014). The role of DNA methylation in stress-related psychiatric disorders. Neuropharmacology, 80, 115-132. doi: 10.1016/j.neuropharm.2014.01.013

LeGris, J., Links, P. S., van Reekum, R., Tannock, R., \& Toplak, M. (2012). Executive function and suicidal risk in women with Borderline Personality Disorder. Psychiatry Research, 196(1), 101-108. doi: 10.1016/j.psychres.2011.10.008

Leichsenring, F., Leibing, E., Kruse, J., New, A. S., \& Leweke, F. (2011). Borderline personality disorder. The Lancet, 377(9759), 74-84. doi: 10.1016/S01406736(10)61422-5

Lynch, T., Rosenthal, M., Kosson, D., Cheavens, J., Lejuez, C., \& Blair, R. (2006). Heightened sensitivity to facial expressions of emotion in borderline personality disorder. Emotion, 6(4), 647-55. doi: 10.1037/1528-3542.6.4.647

Maurex, L., Zaboli, G., Ohman, A., Asberg, M., \& Leopardi, R. (2010). The serotonin transporter gene polymorphism (5-HTTLPR) and affective symptoms among women diagnosed with borderline personality disorder. European Psychiatry, 25(1), 19-25. doi: 10.1016/j.eurpsy.2009.05.001

Maurex, L., Zaboli, G., Wiens, S., Asberg, M., Leopardi, R., \& Ohman, A. (2009). Emotionally controlled decision-making and a gene variant related to serotonin synthesis in women with borderline personality disorder. Scandinavian Journal of Psychology, 50(1), 5-10. doi: 10.1111/j.1467-9450.2008.00689.x

McGowan, P. O. \& Szyf, M. (2010). The epigenetics of social adversity in early life: Implications for mental health outcomes. Neurobiology of Disease, 39(1), 6672. doi: 10.1016/j.nbd.2009.12.026

McCloskeya, M., New, A., Siever, L., Goodman, M., Koenigsberg, H., Flory, J., \& Coccaro, E. (2009). Evaluation of behavioral impulsivity and aggression task as endophenotypes of borderline personality disorder. Journal of Psychiatric Research, 43(12), 1036-1048. doi: 10.1016/j.jpsychires.2009.01.002

Mier, D., Lis, S., Esslinger, C., Sauer, C., Hagenhoff, M., Ulferts, J., ... \& Kirsch, P. (2013). Neuronal correlates of social cognition in borderline personality disorder. Social Cognitive and Affective Neuroscience, 8(5), 531-537. doi: $10.1093 / \mathrm{scan} / \mathrm{nss} 028$

Miller, E. (2010). The prefrontal cortex and cognitive control. Nature reviews neuroscience, 1, 59-65. doi: 10.1038/35036228

Montero, I. \& León, O. G. (2007). A guide for naming research studies in Psychology. International Journal of Clinical and Health Psychology, 7(3), 847-862.

Mueller, S. T. \& Piper, B. J. (2014). The Psychology Experiment Building Language (PEBL) and PEBL Test Battery. Journal of Neuroscience Methods, 222, 250259. doi: 10.1016/j.jneumeth.2013.10.024

O’Neill, A., D’Souza, A., Samson, A. C., Carballedo, A., Kerskens, C., \& Frodl, T. (2014). Dysregulation between emotion and theory of mind networks in borderline personality disorder. Psychiatry Research, 231(1), 25-32. doi: 10.1016/j.pscychresns.2014.11.002

Paris, J. (2008). Treatment of Borderline Personality Disorder: Guide to Evidence Based Practice. New York: Guilford.

Pope, H. G., Jonas, J. M., Hudson, J. I., Cohen, B. M., \& Tohen, M. (1985). An empirical study of psychosis in borderline personality disorder. The American journal of psychiatry, 142(11), 1285-1290. doi: 10.1176/ajp.142.11.1285

Preißler, S., Dziobek, I., Ritter, K., Heekeren, H. R., \& Roepke, S. (2010). Social Cognition in Borderline Personality Disorder: Evidence for Disturbed Recognition of the Emotions, Thoughts, and Intentions of others. Frontiers in behavioral neuroscience, 4, 8. doi: 10.3389/fnbeh.2010.00182

Robin, M., Pham-Scottez, A., Curt, F., Dugre-Le Bigre, C., Speranza, M., Sapinho, D., \& Kedia, G. (2012). Decreased sensitivity to facial emotions in adolescents with Borderline Personality Disorder. Psychiatry Research, 200(2-3), 417-421. doi: 10.1016/j.psychres.2012.03.032

Roepke, S., Vater, A., Preißler, S., Heekeren, H. R., \& Dziobek, I. (2012). Social cognition in borderline personality disorder. Frontiers in Neuroscience, 6, 1-12. doi: $10.3389 /$ fnins. 2012.00195

Sabbagh, M. (2004). Understanding orbitofrontal contributions to theory-of-mind reasoning: implications for autism. Brain and Cognition, 55(1), 209-219. doi: 10.1016/j.bandc.2003.04.002

Svaldi, J., Philipsen, A., \& Matthies, S. (2012). Risky decision-making in borderline personality disorder. Psychiatry Research, 197(1-2), 112-118. doi: 10.1016/j. psychres.2012.01.014

Silvio, V. (2005). Funciones fronto-temporales en pacientes diagnosticados con trastorno límite de la personalidad. Archivos Venezolanos de Psiquiatría y Neurología, 15(104), 30-35.

Stevens, A., Burkhardt, M., Hautzinger, M., Schwarz, J., \& Unckel, C. (2004). Borderline personality disorder: Impaired visual perception and working memory. Psychiatry Research, 125(3), 257-267. doi: 10.1016/j. psychres.2003.12.011

Tajima, K., Montes, A., García-Andrade, R. F., Casado, A., Carrasco, J. L., \& Diaz-Marsá, M. (2009). Estudios de neuroimagen en el trastorno límite de la personalidad. Actas Espanolas de Psiquiatria, 37(3), 123-127.

Tajima, M., \& de Anta, L. (2009). "Trastornos de Personalidad". In M.Munárriz, P. García-Portilla, \& M. Roca. Manual del Residente en Psiquiatría I. Asociación Española de Psiquiatría (AEN), la Sociedad Española de Psiquiatría (SEP) y la Sociedad Española de Psiquiatría Biológica (SEPB). Madrid: España.

Tebartz, L., Hesslinger, B., Thiel, T., Geiger, E., Haegele, K., Lemieux, L., ... \& Ebert, D. (2003). Frontolimbic brain abnormalities in patients with borderline personality disorder: a volumetric magnetic resonance imaging study. Biological Psychiatry, 54(2), 163-171.

Toplak, M. E., Sorge, G. B., Benoit, A., West, R. F., \& Stanovich, K. E. (2010). Decision-making and cognitive abilities: A review of associations between Iowa Gambling Task performance, executive functions, and intelligence. Clinical Psychology Review, 30(5), 562-581. doi: 10.1016/j.cpr.2010.04.002

Unoka, Z., Fogd, D., Füzy, M., \& Csukly, G. (2011). Misreading the facial signs: Specific impairments and error patterns in recognition of facial emotions with negative valence in borderline personality disorder. Psychiatry Research, 189(3), 419-425. doi: 10.1016/j.psychres.2011.02.010

Vaskinn, A., Antonsen, B. T., Fretland, R. A., Dziobek, I., Sundet, K., \& Wilberg, T. (2015). Theory of mind in women with borderline personality disorder or schizophrenia: Differences in overall ability and error patterns. Frontiers in Psychology, 6, 1-7. doi: 10.3389/fpsyg.2015.01239

Villodre, R., Sánchez-Alfonso, A., Brines, L., Núñez, A., Chirivella, J., Ferri, J., \& Noé, E. (2006). Fluencia verbal: estudio normativo piloto según estrategias de «agrupación» y «saltos» de palabras en población española de 20 a 49 años. Neurología, 21(3), 124-130.

Wechsler, D. (1997). WAISS-III Manual. San Antonio: The Psychological Corporation.

Wolf, R., Sambataro, F., Vasic, N., Schmid, M., Thomann, P., Bienentreu, S., \& Wolf, N. (2011). Aberrant connectivity of resting-state networks in borderline personality disorder. Journal of psychiatry \& neuroscience, 36(6), 402-411. doi: 10.1503/jpn. 100150

Yee, L., Korner, A. J., McSwiggan, S., Meares, R. A., \& Stevenson, J. (2005). Persistent hallucinosis in borderline personality disorder. Comprehensive Psychiatry, 46(2), 147-154. doi: 10.1016/j.comppsych.2004.07.032

Zanarini, M. (2000). Childhood experiences associated with the development of borderline personality disorder. Psychiatric Clinics of North America, 23(1), 89-101. doi: 10.1016/S0193-953X(05)70145-3 